\title{
A Review on Methaemoglobinaemia: From Diagnosis to Treatment
}

\author{
Obeagu Emmanuel Ifeanyi* \\ Diagnostic Laboratory Unit, Department of University Health Services, Nigeria
}

Submission: February 14, 2017; Published: May 09, 2018

*Corresponding author: Obeagu Emmanuel Ifeanyi, Diagnostic Laboratory Unit, Department of University Health Services, Michael Okpara University of Agriculture, Umudike, Abia State, Nigeria, Tel: +2348037369912, Email: emmanuelobeagu@yahoo.com

\begin{abstract}
The first case of methaemoglobinaemia was reported by Sloss and Wybauw in 1912. Methaemoglobin is a derivative of normal haemoglobin in which the iron of the haem complex has been oxidized from the ferrous to the ferric form. Methaemoglobin does not combine with oxygen and thus does not take part in oxygen transport. In normal red cells, methaemoglobin is continually being formed by the auto-oxidation of haemoglobin, but it is reduced as soon as it is formed; thus the concentration of methaemoglobin in the red blood cells under normal conditions is less than one percent of total haemoglobin. The term methaemoglobinaemia is used to describe the excess accumulation of methaemoglobin in the red blood cell. Methaemoglobin lacks the capacity to carry oxygen, and methaemoglobinaemia causes symptoms and signs of hypoxia. Toxic methaemoglobinaemia occurs when a drug or other toxic substance oxidizes haemoglobin and the patient is likely to show cyanosis. Methaemoglobinaemia has a wide spread among industrial workers worldwide where they make use of toxic chemicals, also among fertilizer company workers. Methaemoglobin can be identified spectroscopically by its absorption band in the red part of the spectrum at $630 \mathrm{~nm}$; this band disappears on the addition of yellow ammonium sulphide. Methaemoglobin levels are best measured using the change of absorbance of methaemoglobin of $630 \mathrm{~nm}$ that occurs when cyanide is added, converting the methaemoglobin to cyanmethaemoglobin. Treatment consists of slow intravenous injection of methylene blue; the recommended does is $2 \mathrm{mg} / \mathrm{kg}$ bodyweight for infants, $1.5 \mathrm{mg} / \mathrm{kg}$ bodyweight for older children, and $1 \mathrm{mg} / \mathrm{kg}$ bodyweight for adults, in a $1 \%$ sterile aqueous solution.
\end{abstract}

\section{Historical Perspective}

The first case of methaemoglobinaemia was reported by Sloss and Wybauw in 1912. Later Hitzenberger suggested that a hereditary form of methaemoglobinaemia might exist, and subsequently numerous such cases were reported. In 1948, Horlein and Weber described a family in which eight members over four generations manifested cyanosis. The absorption spectrum of methaemoglobin was abnormal. They demonstrated that the defect must reside in the globin portion of the molecule. Subsequently, Singer suggested that such abnormal haemoglobin be given the designation haemoglobin M. The cause of another form of methaemoglobinaemia that occur independently of drug administration and without the existence of any abnormality of the globin molecule or portion of haemoglobin was first explained by Gibson, who clearly pointed out to the site of the enzyme defect, nicotinamide adenine dinucleotide (reduced form of NADH) diaphorases, also designated as methaemoglobin reductase and currently cytochrome b5 reductase. More than 50 years after Gibson's insightful studies, the mutation that he predicted was verified at the DNA level [1].

\section{Methaemoglobin}

Methaemoglobin is a derivative of normal haemoglobin in which the iron of the haem complex has been oxidized from the ferrous to the ferric form [2]. Methaemoglobin can be also be defined as a reversible oxidation product of haemoglobin and can be present in excess amount either because of a hereditary defect in the methemoglobin-reductase system $[1,3,4]$.

Methaemoglobin does not combine with oxygen and thus does not take part in oxygen transport. In normal red cells, methaemoglobin is continually being formed by the autooxidation of haemoglobin, but it is reduced as soon as it is formed; thus the concentration of methaemoglobin in the red blood cells under normal conditions is less than one percent of total haemoglobin [2]. Methaemoglobin has an increased affinity for oxygen and a left shifted oxygen dissociation curve.

According to Beutler [1], when NO is bound by haemoglobin, the hemoglobin is oxidized to methaemoglobin in the reaction:

$$
\mathrm{HbO}_{2}+\mathrm{NO} \longrightarrow \operatorname{metHb}+\mathrm{NO}_{3}^{-}
$$

Removal of NO by haemoglobin may play an important physiologic role and account for the oesophageal pain sometimes encountered in paroxysmal nocturnal haemoglobinuria and for the hypertension occurring after infusion of some experimental haemoglobin solution. The reduction of methaemoglobin is accomplished by the enzyme NADH Methaemoglobin reductase 
(NADH - Cytochrome b5 reductase) in the presence of glycolysis [2].

Methaemoglobin also result from its reaction with certain drugs such as phenacetin or sulphonamides [5]. Methaemoglobin is formed intracellularly and is not found in plasma except when their formation is associated with intravascular haemolysis [6].

According to Ganong [7], methaemoglobin is dark cloured, and when it is present in large quantities in the circulation, it causes a dusky discolouration of the skin resembling cyanosis. Some oxidation of haemoglobin to methaemoglobin occurs normally, but an enzyme system in the blood cell, the NADH Methaemoglobin reductase system converts methaemoglobin back to haemoglobin.

\section{Methaemoglobin Levels}

Methaemoglobin levels vary but may be as high as $40 \%$ of the total haemoglobin [8]. The haematological value for normal adults expressed as a mean \pm 2 SD ( $95 \%$ range) is less than $2 \%$ [9]. Levels of methaemoglobin exceeding 60 to $70 \%$ of the total pigment may be associated with vascular collapse, coma and death, but recovery was documented in one patient with a level as high as $81.5 \%$ of the total pigment [1]. Cyanosis occurs when methaemoglobin constitute about $15 \%$ of the total pigment. When the concentration of methaemoglobin reaches $30-40 \%$ anoxic symptoms commonly develop. In case of acute poisoning, the concentration may exceed 60 to $70 \%$ [2].

According to Lewis \& Roper [6], methaemoglobin is present in small amounts in normal blood and constitute 1 to $2 \%$ of the total haemoglobin. Its concentration is very slightly higher in infants, especially in premature infants, than in older children and adults. About $10 \%$ of methaemoglobin which is equivalent to $15 \mathrm{~g} / \mathrm{l}$ can lead to cyanosis.

\section{Methaemoglobinaemia}

The term methaemoglobinaemia is used to describe the excess accumulation of methaemoglobin in the red blood cell. Methaemoglobin lacks the capacity to carry oxygen, and methaemoglobinaemia causes symptoms and signs of hypoxia. The great majority of cases of methaemoglobinaemia are due to the action of chemical agents that increase the rate of auto oxidation of haemoglobin in the red blood cells [2].

According to Hoffbrand et al. [10], methaemoglobinaemia is a clinical state in which circulating haemoglobin is present with iron in the oxidized $(\mathrm{Fe}+3)$ instead of the usual $\mathrm{Fe}+2$ state. It may arise because of a hereditary deficiency of reduced nicotinamide adenine dinucleotide (NADH) diaphorase or inheritance of structurally abnormal haemoglobin (HbM). These contain an amino acid substitution affecting the haem pocket of the globin chain.

According to Vassilliou \& Green [11], methaemoglobin has an increased affinity for oxygen and a left-shifted oxygen dissociation curve. Pathological acquired methaemoglobinaemia can result from exposure to strong oxidants (e.g. dapsone, paraquat, benzocaine) and can be life- threatening when severe but is rarely sufficiently long-lived to give rise to polycythaemia.

According to Bradberry et al. [12], methaemoglobinaemia has occurred as a result of accidental contamination of drinking water with sodium nitrite.

\section{Sources of Toxic Methaemoglobinaemia}

Toxic methaemoglobinaemia occurs when a drug or other toxic substance oxidizes haemoglobin and the patient is likely to show cyanosis [10]. Occupational cause of toxic methaemoglobinaemia in industries is most commonly due to absorption of nitro and amino aromatic derivatives. The substances are usually absorbed through the respiratory tract or skin, and the disorder is most often seen in workers in chemical factories and explosive plants. Well water sometimes contains high concentration of nitrates, and in country areas the use of this water to prepare milk mixtures for infants has resulted in methaemoglobinaemia [2].

According to Beutler [1], nitrates, and nitrites contaminating water supplies or used as preservatives in foods are also common offending agents that can provoke toxic methaemoglobinaemia. According to Gordon-Smith et al. [13], nitrites in water or vegetable juices may cause methaemoglobinaemin in infants who have a physiological impairment of the reducing systems. Well water that comes from land with an excess of nitrites and which is used to reconstitute artificial feeds has produced cyanosis in infants. Cases have also been reported and described following the enthusiastic feeding of juice from carrots grown on artificially or organically fertilized land and of spinach juice.

\section{Epidemiology of Methaemoglobinaemia}

Methaemoglobinaemia has a wide spread among industrial workers worldwide where they make use of toxic chemicals, also among fertilizer company workers [10]. Toxic methaemoglobinaemia is sporadic in nature but is clearly related to industrial exposure, and is therefore most common among workers in the chemical industries [1].

\section{Clinical Features of Methaemoglobinaemia}

Methaemoglobinaemia may be chronic or acute. Severe acute methaemoglobinaemia, usually the consequence of drug ingestion or toxic exposure, can produce symptoms of anaemia, since methaemoglobin lacks the capacity to transport oxygen. Symptoms may include shortness of breath, palpitations, and vascular collapse. Chemicals that induce methaemoglobinaemia are often also capable of causing haemolysis and a combination of haemolytic anaemia and methaemoglobinaemia may occur. Chronic methaemoglobinaemia, whether as a result of exposure to drugs or toxins or due to hereditary causes is usually asymptomatic. In instances when the methaemoglobin levels are very high $(>20 \%$ of total pigment) mild erythrocytosis is occasionally noted [1]. 
Cyanosis occurs when methaemoglobin constitute about $15 \%$ of total pigment. In many cases, there are no clinical features other than cyanosis, but when methaemoglobin concentration reaches 30 to $45 \%$ symptoms like headache, dizziness, tachycardia, dyspnoea on exertion, muscular cramps and weakness commonly develop. In cases of acute poisoning, the concentration may exceed 60 to $70 \%$, and vomiting, lethargy, loss of consciousness, circulatory failure and death may occur. In acute cases, the cyanosis develops within 1-2hours of the ingestion of the toxic agent. In chronic methaemoglobinaemia, a mild compensatory polycythemia occasionally develops. Many of the substances that cause methaemoglobinaemia may also cause haemolytic anaemia with Heinz-body formation [2].

\section{Laboratory Diagnosis of Methaemoglobinaemia}

Methaemoglobin can be identified spectroscopically by its absorption band in the red part of the spectrum at $630 \mathrm{~nm}$; this band disappears on the addition of yellow ammonium sulphide. When it is present in large amounts, the blood has a chocolatebrown colour which does not disappear on oxygenation. Methaemoglobin does not appear in the plasma or urine except in occasional cases with associated haemolytic anaemia [2].

In toxic methaemoglobinaemia an elevated level of methaemoglobin is found but the activity of NADH diaphorase is normal. Methaemoglobin levels are best measured using the change of absorbance of methaemoglobin of $630 \mathrm{~nm}$ that occurs when cyanide is added, converting the methaemoglobin to cyanmethaemoglobin. Error in diagnosis are frequently made when automated instruments designed to estimate levels of reduced haemoglobin, oxygenated haemoglobin, methaemoglobin, and carboxyhaemoglobin are used. Most automated instruments do not properly make this distinction and direct spectrophotometric analysis should be used when methaemoglobinaemia is suspected [1].

\section{Therapeutics for Methaemoglobinaemia}

Following removal of the causative agent, methaemoglobin is converted back to haemoglobin in a few days. Thus in chronic cases elimination of the causative drug or chemical results in disappearance of the cyanosis within several days. In cases of acute methaemoglobinaemia due to poisoning, especially when symptoms are severe, more active treatment is necessary. Treatment consists of slow intravenous injection of methylene blue; the recommended does is $2 \mathrm{mg} / \mathrm{kg}$ bodyweight for infants, $1.5 \mathrm{mg} / \mathrm{kg}$ bodyweight for older children, and $1 \mathrm{mg} / \mathrm{kg}$ bodyweight for adults, in a $1 \%$ sterile aqueous solution [2].

\section{Conclusion}

The term methaemoglobinaemia is used to describe the excess accumulation of methaemoglobin in the red blood cell. Methaemoglobin lacks the capacity to carry oxygen, and methaemoglobinaemia causes symptoms and signs of hypoxia. Toxic methaemoglobinaemia occurs when a drug or other toxic substance oxidizes haemoglobin and the patient is likely to show cyanosis. Methaemoglobinaemia has a wide spread among industrial workers worldwide where they make use of toxic chemicals, also among fertilizer company workers. Methaemoglobin can be identified spectroscopically by its absorption band in the red part of the spectrum at $630 \mathrm{~nm}$; this band disappears on the addition of yellow ammonium sulphide. Methaemoglobin levels are best measured using the change of absorbance of methaemoglobin of $630 \mathrm{~nm}$ that occurs when cyanide is added, converting the methaemoglobin to cyanmethaemoglobin. Treatment consists of slow intravenous injection of methylene blue.

\section{References}

1. Beutler E (2006) Disorders of Haemoglobin Structure: Sickle Cell Anaemia and Related Abnormalities. In: Lichtman MA, Beutler E, Kipps TJ, (Eds.), Williams Hematology. ( $7^{\text {th }}$ edn), Mc Graw Hill, USA, pp. 671672.

2. Ramnik S (2003) Haematology for Students and Practitioners. $\left(5^{\text {th }}\right.$ edn). Jaypee Brothers Medicals Publishers Ltd, New Delhi, India, P. 108-181.

3. Christian SG, Obeagu EI, Jacob RB, Ihua N (2015) Effect of occupational exposure hazards on methaemoglobin level of abattoir workers. International Journal of Advanced Multidisciplinary Research (IJAMR). 2(11): 86-91.

4. Obeagu EI, Odo MC, Emelike CU, Ogbodo OR (2013) Determination of Levels of Methaemoglobin in Sickle Cell Patients in Abakaliki, Ebonyi State, Nigeria. International Journal of Research and Reviews in Pharmacy and Applied science. 3(4):554-560.

5. Ochei J, Kolhatkar A (2000) Medical Laboratory Science Theory and Practice. Tata McGraw Hill Publishing Company Limited, New Delhi. India pp. 275.

6. Lewis SM, Roper D (2006) Laboratory Methods Used in the Investigation of the Haemolytic Anaemias. In: Lewis SM, Bain BJ, Bates I (Eds.), Practical Haematology. (10 ${ }^{\text {th }}$ edn), Churchill Livingstone, Philadelphia. USA, pp. 200-222.

7. Ganong W F (2005) Review of Medical Physiology. ( $22^{\text {nd }}$ edn), McGraw Hill, USA, P. 534.

8. Wild B, Bain BJ (2006) Investigation of Abnormal Haemoglobins and Thalassaemia. In: Lewis SM, Bain BJ, bates I Practical Haematology. ( $10^{\text {th }}$ edn), Churchill Livingstone, Philadelphia, USA, p. 295.

9. Lewis SM (2006) Reference Ranges and Normal Values. In: Lewis SM, Bain BJ, bates I (Eds.), Practical Haematology, (10 ${ }^{\text {th }}$ edn). Churchill Livingstone, Philadelphia, USA, P. 15.

10. Hoffband AV, Moss PAH, Pettit JE (2006) Essential Haemotology. (5 $5^{\text {th }}$ edn). Blackwell Publishing, USA, P. 18.

11. Vassiliou G, Green AR (2005) Myeloproliferative Disorders. In: Hoffbrand AV, Catovsky D, Tuddenham EGD (Eds.), Postgraduate Haematology. ( $5^{\text {th }}$ edn), Blackwell Publishing, USA, PP. 766-767.

12. Bradberry SM, Gassard B, Vale JA (1994) Methaemoglobinaemia Caused by the Accidental Contamination of drinking water with Sodium Nitrate. J Toxicol Clin Toxicol 32: 173.

13. Gordon-smith EC, Narsh JCW (2005) Acquired Haemolytic Anamias. In: Hoffbrand AV, Catovsky D, Tuddenham EGD (Eds.), Postgraduate Haematology. $\left(5^{\text {th }}\right.$ edn $)$, Blackwell Publishing, USA, pp. 166-167. 
Your next submission with Juniper Publishers will reach you the below assets

- Quality Editorial service

- Swift Peer Review

- Reprints availability

- E-prints Service

- Manuscript Podcast for convenient understanding

- Global attainment for your research

- Manuscript accessibility in different formats ( Pdf, E-pub, Full Text, Audio)

- Unceasing customer service

Track the below URL for one-step submission https://juniperpublishers.com/online-submission.php 